\author{
Szymon Trusewicz \\ Kolegium Literaturoznawstwa \\ Wydział Filologiczny \\ Uniwersytet w Białymstoku \\ e-mail: sztr@o2.pl \\ ORCID: 0000-0002-4313-7256
}

\title{
Nekrolog jako składnik elegijnego świata poetyckiego i jako tekst metapoetycki w wybranych utworach Eugeniusza Tkaczyszyna-Dyckiego
}

Świat kreowany przez Eugeniusza Tkaczyszyna-Dyckiego w jego poezji postrzega się często przez pryzmat melancholii, smutku i śmierci. Alina Świeściak mówi o "pustej obecności” obiektów wypełniających poetycki świat autora Kochanki Norwida: „Przypomina on (ów świat) miejsce wymarłe lub miejsce umierania; jest tym, co pozostało po zmarłych, lub przestrzenią, w której - i z której (nieustannie, wielokrotnie) - odchodzą żywi"1. Jednym z typowo funeralnych motywów wykorzystywanych przez Tkaczyszyna-Dyckiego jest nekrolog. Jego obecność bez wątpienia pozwala wzmocnić nostalgiczno-melancholijną aurę opisywanego świata, tak jak ma to miejsce w wierszu CCCXLI., w którym nekrologi czyta obserwowana przez poetę dziewczyna:

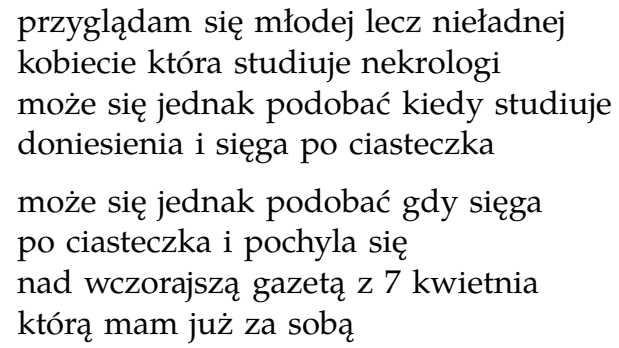

1 A. Świeściak, Śmiertelne sublimacje. Eugeniusz Tkaczyszyn-Dycki, w: tejże, Melancholia w poezji polskiej po 1989 roku, Kraków 2010, s. 148. 
ale nade wszystko jest w niej coś z nieuchwytnego piękna kiedy dostrzega nazwiska owych Kępskich Widawskich i Traczewskich które jej nic nie mówią ${ }^{2}$.

Nekrolog funkcjonuje jako składnik opisu podpatrzonej przez bohatera sceny w miejskiej kawiarni. Podmiot przyjmuje w tym wierszu perspektywę obserwatora zainteresowanego codziennym zdarzeniem rozgrywającym się w przestrzeni miasta. Chociaż wiersz kończy charakterystyczna dla Tkaczyszyna-Dyckiego refleksja o przemijaniu, wzbogacona o wspomnienie wymienionych z nazwiska zmarlych, swoją strukturą odbiega on od innych utworów. Wyróżnia go nie samo zainteresowanie codziennością czy banałem, często pojawiające się w poezji Tkaczyszyna-Dyckiego, ale perspektywa, którą przyjmuje podmiot mówiący $\mathrm{w}$ wierszu. Zainteresowany światem zewnętrznym próbuje uchwycić, niczym w obiektywie aparatu, interesującą go scenę. Na tego rodzaju obserwacje pozwala typowo miejski krajobraz - kawiarni lub restauracji - umożliwiający zarówno swobodną obserwację, jak i bycie obserwowanym. Typowa dla wierszy autora Kochanki Norwida bezpośrednia refleksja nad własnym "ja" w powyższym utworze współistnieje z kreacją podmiotu-obserwatora. Perspektywa ,ja" skoncentrowanego na swoich emocjach i przeżyciach $w$ dwóch pierwszych strofach zdaje się być wyciszona, przypominając o obecności mówiącego poety dopiero $\mathrm{w}$ ostatniej zwrotce. Jego skoncentrowanie się na opisie sceny i jasno zaznaczony punkt widzenia („przyglądam się"), przypomina skupienie malarza lub fotografa. Jeśli pozostać przy skojarzeniach malarskich, obecny $\mathrm{w}$ wierszu motyw vanitas skłania do porównań z Młodzieńcem z czaszka pędzla Fransa Halsa, w którym kontrastują ze sobą młodość i śmierć. W wierszu postać dziewczyny przeciwstawiona zostaje konotującym śmierć nekrologom.

Bohaterce utworu Tkaczyszyna-Dyckiego nazwiska zmarłych "nic nie mówią", dlatego podchodzi do zawartej w nekrologach informacji obojętnie. Choć uwaga podmiotu mówiącego, a także czytelnika, koncentruje się na dziewczynie, to można scharakteryzować również postać obserwatora. Opis czynności, które wykonuje bohaterka, stanowi negatyw stanu emocjonalnego podmiotu mówiącego, jego zainteresowania osobami wymienionymi w nekrologu. Poeta nie mówi wprost o tym, że są one ważne ze względu na osobistą znajomość, nie zdradza, czy kieruje nim ciekawość, czy każąca zagłębiać się w lekturze wszystkich nekrologów melancholia. Na melancholijne usposobienie wskazuje kontekst innych utworów, ukazujący mówiącego

\footnotetext{
2 E. Tkaczyszyn-Dycki, Oddam wiersze w dobre ręce (1988-2010), Wrocław 2010, s. 318. Kolejne cytaty z tego zbioru lokalizuję w tekście głównym, oznaczając je skrótem OW.
} 
jako osobę, która chętnie wraca myślą do przeszłości. Choć emocje, jakie budzi w Tkaczyszynie-Dyckim obecność nazwisk w nekrologu, nie zostały wypowiedziane wprost, wiele wskazuje na to, że są one intensywniejsze niż odczucia obojętnie przeglądającej treść gazety dziewczyny. Zdziwiony jej obojętnością poeta dał się poznać jako znający historię województwa przemyskiego i śledzący losy rodziny, sąsiadów i znajomych. Można podejrzewać, że Tkaczyszyn-Dycki, mówiąc o „nieuchwytnym pięknie” dziewczyny, ma na myśli fascynującą go niewiedzę czytelniczki. Idealizowana dziewczyna nie spogląda na świat oczami wyobcowanego bohatera, który w rzeczywistości dostrzega przede wszystkim śmierć i przemijanie. Odpowiednio dobrana sceneria przestrzeni miejskiej pozwala dopełnić kreowaną w wierszu figurę osamotnionego twórcy. Poetę i dziewczynę dzieli dystans, co skłania do voyeurystycznej konwencji opisu, nieczęstej w przypadku utworów Tkaczyszyna-Dyckiego. Inaczej niż zwykle, przekierowuje on swoją uwagę ze świata przeszłości na teraźniejszość, zastępując introspekcję ekstraspekcją. Nie przekłada się to na wyciszenie łatwo rozpoznawalnego głosu melancholijnego ,ja". Ze względu na kontrast pomiędzy postrzeganiem świata przez poetę i przez dziewczynę wiersz akcentuje towarzyszące mówiącemu poczucie niezrozumienia. Poprzez kontrastowe przedstawienie sytuacji Tkaczyszyn-Dycki wyraża poczucie obcości i samotności równie skutecznie, jak w przypadku bardziej bezpośredniego lirycznego wyznania.

Obecność nekrologu w poezji Tkaczyszyna-Dyckiego służy zbudowaniu nastroju elegijnego, jeśli przyjąć rozumienie elegijności sformułowane przez Marcina Jaworskiego i Piotra Śniedziewskiego we wstępie do monograficznego numeru „Poznańskich Studiów Polonistycznych”. Badacze określają elegijność jako „szczególną modalność wypowiedzi, w której najważniejsza okazuje się emocjonalna sytuacja podmiotu lirycznego, refleksje poświęcone przemijaniu oraz wanitatywne krajobrazy"3. Z kolei Anna Legeżyńska elegijność definiowała w książce Gest pożegnania. Szkice o poetyckiej świadomości elegijno-ironicznej jako „aurę emocjonalną wiersza”, która „buduje temat przemijania i nostalgiczno-melancholijne, a niekiedy depresyjne samopoczucie podmiotu" ${ }^{4}$. Elegijny charakter wierszy Tkaczyszyna-Dyckiego jest dobrze widoczny w utworze CCCXLI. Nekrolog służy odmalowaniu stanu psychicznego jednostki, która na otaczający świat patrzy z melancholijnej, skoncentrowanej na utracie perspektywy.

3 M. Jaworski, P. Śniedziewski, Od redakcji, „Poznańskie Studia Polonistyczne” 2011, nr 18, s. 7.

4 A. Legeżyńska, Gest pożegnania. Szkice o poetyckiej świadomości elegijno-ironicznej, Poznań 1999, s. 17. 
Specyfika nekrologu, który jest nie tylko wyposażonym w funeralne skojarzenia artefaktem, ale również tekstem, każe przypuszczać, że rola tego motywu nie wyczerpuje się na jego elegijnej funkcji. Scena czytania nekrologu, z jaką mamy do czynienia w wierszu CCCXLI., prowadzi do wykreowania sytuacji komunikacyjnej „tekstu w tekście”, co skłania do rozpatrywania znaczenia tego motywu z perspektywy metapoetyckiej ${ }^{5}$. Refleksja metapoetycka zazwyczaj wypowiadana jest w sposób nieutajony, to znaczy taki, w którym pojawiają się nazwy czynności twórczych, jednak może być komunikowana na różne sposoby ${ }^{6}$. Włączenie przez Tkaczyszyna-Dyckiego $w$ treść swojego wiersza innego tekstu, w tym przypadku nekrologu, każe zastanowić się nad odczytaniami, na jakie otwiera swój utwór poeta. Nekrolog-tekst jest przez badaczy definiowany ze względu na komunikat, który przekazuje. Jacek Kolbuszewski pisze, że jest to „specyficzny gatunek prasowy o prymarnej funkcji informacyjnej (wiadomość o zgonie) i inseratowej (ogłoszenie o czasie i miejscu, czasem nawet formie, uroczystości pogrzebowych, bądź ich symbolicznego substytutu)"'7. Tkaczyszyn-Dycki bez wątpienia ma świadomość tekstologicznej specyfiki nekrologu, gatunku bardzo niejednorodnego, który jest ogłoszeniem prasowym, płatnym, wykonywanym często na zamówienie ${ }^{8}$, i spełnia funkcję informacyjną, a jednocześnie jest tekstem

5 Pojęcie to traktuję jako najszersze do określania różnych praktyk wskazujących na samoświadomość literatury, takich jak metaliterackość, autorefleksja, autokomentarz, autotematyzm.

6 Parafrazuję tu rozważania Michała Głowińskiego, który metapoetyckość ogranicza do utworów „w których bezpośrednio, w sposób mniej lub bardziej jawny, mówi się o poezji, w których występują takie czy inne nazwy czynności twórczych" [M. Głowiński, Słowo i pieśń, w: tegoż, Zaświat przedstawiony. Szkice o poezji Bolesława Leśmiana, Kraków 1998, s. 53, podkr. - S.T.]. To ograniczenie wynika z wieloznacznego charakteru poezji Leśmiana, którego Głowiński nie chciał interpretacyjnie uprościć - „rozszyfrować”. Jednak jest ono znaczące, gdy przywołać uwagę poczynioną w tekście Powiesśc jako metodologia powieści. Otóż w „powieści myślącej o sobie samej”, widoczna jest "immanentna metodologia literacka”, która jest zespołem mniemań zawartych przez autora świadomie „w sposób jawny lub utajony w dziele na temat zespołu użytych w nim operacji literackich i materiału, w jakim się one dokonują" [M. Głowiński, Powieść jako metodologia powieści, w: tegoż, Intertekstualność, groteska, parabola. Szkice ogólne i interpretacje, Kraków 2000, s. 128, podkr. - S.T.]. Głowiński czyni więc rozróżnienie pomiędzy komunikowaniem treści autotematycznych w poezji i prozie.

7 J. Kolbuszewski, Z głębokim żalem... O wspótczesnej nekrologii, Wrocław 1997, s. 23.

8 Jacek Kolbuszewski, pisząc o graficznym wyglądzie nekrologów, zauważa, że w gazetach ułożone one są zwykle na jednej stronie, wchodząc ze sobą w różne konwergencje. „Niekiedy jednak przybierają one postać nad wyraz oryginalną, gdy kilka instytucjonalnych nekrologów dotyczących tej samej osoby, ale podpisanych przez różne instytucje, ma formę literalnie identyczną. Dla czytelnika może to być wówczas źródłem informacji bardziej kuriozalnej niż istotnej, acz wyrażającej pewien sens, że autorem kilku nekrologów była jedna i ta sama, może wypełniająca instytucjonalne zlecenia, osoba" [J. Kolbuszewski, Z głębokim żalem..., s. 40]. 
o charakterze literackim, bardzo intymnym w treści, o wysokim zabarwieniu emocjonalnym ${ }^{9}$.

Wiersz o dziewczynie czytającej gazetę $\mathrm{w}$ kawiarni i przyglądającym się jej poecie jest autokomentarzem zagłębiającej się we własne stany emocjonalne jednostki, jednak kryje się $\mathrm{w}$ tej refleksji cień ironii. Utwór nie utrzymuje poważnego nastroju, cała opisywana sytuacja jest $\mathrm{w}$ subtelny sposób komiczna, trudno zatem ograniczyć się w interpretacji jedynie do wskazania negatywnej refleksji podmiotu bolejącego nad swoim stanem egzystencjalnym. Z fascynacją przygląda się on osobie, która inaczej niż on, beznamiętnie, spogląda na nekrolog. Obecność ironii, środka literackiego wymagającego dystansu nadawcy do własnego komunikatu, pozwala odczytywać CCCXLI. jako rodzaj metapoetyckiego komentarza odnoszonego do własnej twórczości, w której niemożliwe jest pominięcie faktu śmierci Kępskich, Widawskich czy Traczewskich. Najważniejsza z tej perspektywy jest ostatnia zwrotka:

ale nade wszystko jest w niej coś $\mathrm{z}$ nieuchwytnego piękna kiedy dostrzega nazwiska owych Kępskich Widawskich

i Traczewskich które jej nic nie mówią

[CCCXLI., OW, s. 381]

Wiersz CCCXLI. można odczytywać jako scenkę rodzajową, która w sposób metaforyczny przedstawia poetę przyglądającego się czytelnikowi swoich wierszy. Znak rozpoznawczy w powyższym fragmencie stanowią charakterystyczne dla poezji Tkaczyszyna-Dyckiego powtórzenie i wyliczenia, szczególnie te dotyczące nazw własnych. Wiersz jest autokomentarzem do wyborów stylistycznych poety, czemu służy ironiczny opis reakcji czytelniczki, dostrzegającej „nazwiska owych Kępskich Widawskich / i Traczewskich które jej nic nie mówią". Dziewczyna czyta gazetowy nekrolog, ale równie dobrze mogłaby czytać wiersz Tkaczyszyna-Dyckiego, pełen nic niemówiących nazwisk zmarłych. Wprowadzenie do treści wiersza bohaterki-czytelniczki, która przygląda się bez większego zrozumienia wymienionym w nekrologach-wierszach nazwiskom, pozwala wykreować sytuację liryczną, w której refleksji na temat egzystencji, losu czy śmierci towarzyszy refleksja metapoetycka. Autotematyczny wymiar wiersza nie wyklucza szczerego opisu wyobcowania bohatera, każe jednak dostrzec w tym doświadczeniu inny aspekt, związany z aktem lektury-pisania. Jeśli posłużyć się metaforą przestrzenną, autoironiczna postawa Tkaczyszyna-Dyckiego pozwala przyjąć mu pozycję

\footnotetext{
9 Tamże, s. 6.
} 
optymalnego dystansu wobec własnych wierszy. Nie jest ona na tyle odległa, by wzbudzić w odbiorcy podejrzliwość o wyrachowaną grę konwencjami, nie jest też na tyle bliska, by posądzić poetę o posługiwanie się wyeksploatowanymi kliszami. Miejsce, które w tym układzie zajmuje Tkaczyszyn-Dycki, pozwala na dwuznaczne wykorzystanie nekrologu. Jako przedmiot stanowi element świata przedstawionego, służy zatem do opowiedzenia o wyobcowaniu bohatera. Nekrolog rozumiany jako metafora tekstu poetyckiego pozwala na autotematyczną refleksję nad twórczością.

Metapoetycką funkcję spełnia nekrolog $\mathrm{w}$ wierszach $\mathrm{z}$ tomu Piosenki o zależnościach i uzależnieniach, w których stanowi składnik antytezy „księgozbiory nie są". W wierszu CCCXXXV. nekrolog przeciwstawiony zostaje przez poetę księgozbiorom:

bądźmy szczerzy księgozbiory nie są nam dziś potrzebne przeczytaj nekrolog Stefana Piotra Strześniewskiego (1928-2006) lub Danieli Głąbińskiej (1921-2006)

nie opowiadaj więc o przepastnych rodzinnych bibliotekach niczego od ciebie nie wezmę ale nie oddalaj się ode mnie napisz koniecznie i bezzwłocznie długi list po powrocie do Wielkich Oczu wybacz mój drogi księgozbiory nie są nam już niezbędne do życia musisz się z tym pogodzić przeczytaj nekrolog częstochowianki Głąbińskiej [CCCXXXV., OW, s. 375]

Jeśli przyjąć, że księgozbiór stanowi dla Tkaczyszyna-Dyckiego synonim literatury, czyli zbioru tekstów napisanych w większości przez ludzi już nieżyjących, które opowiadają również o osobach martwych, to przeciwstawienie jej nekrologom byłoby ironiczne. Początek drugiej strofy wskazuje, że księgozbiór nie musi oznaczać dla Tkaczyszyna-Dyckiego literatury w ogóle. Wiersze o domu poety, na przykład te o pokoju bibliotecznym (OW, s. 295, 398-399), świadczą, że traktuje on księgozbiory jako obiekty materialne i kojarzy je z domową biblioteką wypełnioną książkami, dokumentami, rękopisami. Przewaga nekrologu nad księgozbiorem wynika zatem $\mathrm{z}$ jego pragmatycznego charakteru, wiążącego go ze światem realnym, a nie wyobrażonym. $Z$ jednej strony Tkaczyszyn-Dycki, porównując księgozbiór do nekrologu, akcentuje różnice gatunkowe pomiędzy tymi tekstami oraz różnice $\mathrm{w}$ stopniu ich autentyczności. Za tekstem prasowym informującym 
o śmierci zawsze stoi konkretny i rzeczywisty fakt zgonu człowieka ${ }^{10} . \mathrm{Z}$ drugiej strony porównanie nekrologu i księgozbioru rozumianego jako materialne archiwum uwydatnia pragmatyczne aspekty wykorzystania różnych tekstów, mówi o ich związku z codziennością. Nekrolog, w przeciwieństwie do księgozbioru, jest bliższy życiu i codzienności. Tkaczyszyn-Dycki pokazuje jednocześnie różnicę pomiędzy oboma rodzajami wypowiedzi i mówi, że zamiast przeszukiwać archiwum, należy sięgnąć po codzienną gazetę, odwrócić się od tego, co przeszłe ${ }^{11}$ i fikcyjne. Postacią, która postępuje w ten sposób, jest dziewczyna-czytelniczka z poprzednio omawianego wiersza. Wolna od trudnych doświadczeń bohatera mówiącego i jego melancholijnego spojrzenia na świat i przeszłość, skupia się na teraźniejszości. Poeta jednak pozostaje związany pętami "przepastnych rodzinnych bibliotek”, symbolizujących rodzinne dziedzictwo i przeszłość, których nie może odrzucić.

W wykorzystującym podwójną funkcję nekrologu jako atrybutu elegijnego i metapoetyckiego wierszu CCCLXXVI. Tkaczyszyn-Dycki zestawia ze sobą dwa różne zdarzenia: śmierć sąsiadki i wyjście na zakupy. Wychodząc z domu, autor przystaje, by przyznać przed samym sobą: "tyle jest spraw do omówienia i przedstawienia w poezji chociażby śmierć sąsiadki" [CCCLXXVI., OW, s. 418, podkr. - S.T.]. Wskazuje on w ten sposób nie tylko na śmierć jako temat swoich codziennych rozważań, ale również na problem przedstawienia śmierci w poezji. Nekrolog informujący o zgonie Heleny Wielogórskiej stanowi nie tylko memento mori, ale kieruje ku rozważaniom nad poetyką służącą opowiedzeniu o śmierci sąsiadki. Utwór traktuje o przerwaniu rytmu codziennych czynności spowodowanym tą wiadomością:

\author{
tyle jest spraw do omówienia \\ w poezji chociażby śmierć \\ Wielogórskiej którą w tym wierszu \\ chciałbym zapewnić o pamięci \\ przeczytałem dziś wybierając się po drobne \\ zakupy nekrolog Heleny Wielogórskiej \\ z domu Janowszczyńskiej tyle jest spraw \\ za którymi wychodzi się na miasto
}

\footnotetext{
10 Tamże, s. 5.

11 Czyli dokonać niemożliwego: „Dycki jest trochę jak anioł historii Benjamina, który krzykiem oddala się od raju, a może widzieć przed sobą tylko ogromniejące ruiny, gdyż porusza się plecami do przyszłości. Tyle że Dycki prawie nigdzie nie leci, bo od razu uderza plecami o koniec. Koniec zaś jest równie nieopowiadalny jak fantastyczny początek: hipostazuje się w obłędzie kolejnych pogrzebów" [A. Sosnowski, Liryzm Dyckiego, w:,,jesień już Panie a ja nie mam domu". Eugeniusz Tkaczyszyn-Dycki i krytycy, red. G. Jankowicz, Kraków 2001, s. 46].
} 
gdybym zaś nie poszedł do sklepu nie zatrzymałbym się z siatką w ręku i nie przyznał sam przed sobą: tyle jest spraw do omówienia i przedstawienia w poezji chociażby śmierć sąsiadki [CCCLXXVI., OW, s. 418]

Przerwane lekturą nekrologu wyjście po zakupy staje się centralnym wydarzeniem, które inspiruje napisanie wiersza. Doświadczenie to, ze względu na kontrastujące zestawienie zakupów i śmierci, jest na tyle niejednolite i niespójne, że stanowi zasadę organizującą wiersz pod względem formalnym. Widoczne jest to $\mathrm{w}$ figurze pętli, którą przyjmuje utwór, wszak śmierć Wielogórskiej stanowi powód do napisania wiersza na ten temat, jednak napisanie wiersza wiąże się z refleksją o poezji, to zaś wynika z myśli, którą przywodzi wyjście na zakupy, któremu towarzyszy przeczytanie nekrologu... Skomplikowanie komunikatu o śmierci Wielogórskiej, który przekazuje wiersz, wynika z samej wiadomości o śmierci. Niejasne następstwo zdarzeń zakłóca odbiór utworu, przez co czytelnik odczuwa dezorientację i zagubienie. Są to odczucia towarzyszące sytuacji, o której wiersz pośrednio opowiada - informacji o śmierci, która przerywa codzienne czynności.

Anakolutyczna struktura wiersza nie byłaby tak widoczna, gdyby nie okalająca utwór klamra. Pierwsza strofa i ostatnie dwa wersy utworu stanowią ramę, która warunkuje dalszy jego odbiór jako wiersza o charakterze metapoetyckim. Tkaczyszyn-Dycki stawia w tych fragmentach zasadnicze dla sztuki poetyckiej pytania o tematykę i formę wiersza, jak również możliwość odpowiedniej artykulacji faktu śmierci Heleny Wielogórskiej. Zarysowana $\mathrm{w}$ ten sposób sytuacja liryczna dotyczy aktu pisania, ale również szerzej aktu komunikowania. Wprowadzenie do wiersza kontekstu sytuacji pisania-czytania pozwala rozwinąć sytuację liryczną poza dosłownym „przedstawieniem" czy „omówieniem” problemu śmierci Heleny Wielogórskiej. Tkaczyszyn-Dycki stosuje anakolut, aby przybliżyć czytelnikowi zdarzenie, którego doświadczył. Poecie udaje się upamiętnić śmierć Heleny Wielogórskiej, nie traktując tego zdarzenia wyłącznie jako pretekstu. Unika przy tym sformułowań „chciałbym upamiętnić" czy "chciałbym wspomnieć”, pisząc „,w tym wierszu / chciałbym zapewnić o pamięci" i określając swoją intencję jako skierowaną z jednej strony na upamiętnienie śmierci Wielogórskiej, z drugiej na sam akt wypowiedzi.

Przypomnieć można, że autoreferencjalność wypowiedzi łączy się z jej funkcją poetycką, którą tradycyjne określa się jako przejaw nadorganizacji 
tekstu. Wynika ona ze skomplikowania komunikatu, w którym jednostki, jak stwierdza Janusz Sławiński, „odgrywają wiele ról na raz, są uwikłane w szereg równoczesnych zobowiązań, są - jeśli można tak powiedzieć użyte wielokrotnie w tym samym miejscu sekwencji" ${ }^{12}$. W efekcie "funkcja poznawcza języka ulega metodycznemu osłabieniu; świat, o którym komunikuje utwór, «migoce» spoza gęstej sieci zależności międzyznakowych i międzyznaczeniowych" ${ }^{\prime 13}$. Z tej perspektywy badawczej wprowadzenie do tekstu sytuacji pisania-czytania może służyć osłabieniu funkcji poznawczej wiersza, gdyż nie odsyła czytelnika bezpośrednio do wyrażanych przeżyć czy opisywanych rzeczy. Nieco inaczej na akt pisania-czytania nekrologu przez Tkaczyszyna-Dyckiego pozwala spojrzeć poetyka doświadczenia Ryszarda Nycza, według którego metapoetyckie działania autora nie osłabiają funkcji poznawczej. Nycz wskazuje, że badanie „przedstawienia w przedstawieniu” nie jest poznaniem mniej wartościowym czy pozornym:

wypowiedź nie jest wskazaniem (referencją) oraz opisaniem uprzedniego i niezależnego od niej przedmiotu, lecz w całości jawi się jako równoczesny akt ukazywania/formowania przedmiotu poprzez artykulację jego własności. Można by powiedzieć, że każde przedstawienie jest konstrukcją i interpretacją tego, co przedstawione, a jego kształt, porządek, znaczenie nie dają się oddzielić od warunków i cech jego artykulacji ${ }^{14}$.

Nycz ukazuje w ten sposób tropiczną naturę literatury jako formy poznania skoncentrowanej na samym przedstawiającym i doświadczającym. Poeta doświadcza i siebie, i artykułowanego w twórczości życia po raz wtóry, poprzez organizację faktów i emocji w porządku języka literackiego. Organizacja chaosu życiowych doświadczeń może przybierać różną formę $\mathrm{w}$ zależności od użytych środków poetyckich, pozwalających przekształcić „bezprzedmiotową miazgę doświadczenia” ${ }^{15}$. W tym kontekście zaburzona struktura wiersza CCCLXXVI. ukazuje doświadczenie śmierci Heleny Wielogórskiej jako zdarzenie wieloznaczne i wielopoziomowe, co pozwala poecie ustrzec się przed naiwną dosłownością w artykulacji doświadczenia. Treść utworu każe również dostrzec w Tkaczyszynie-Dyckim poetę traktującego opisywane $\mathrm{w}$ poezji osoby w sposób etyczny i odpowie-

\footnotetext{
12 J. Sławiński, Semantyka wypowiedzi narracyjnej, w: tegoż, Dzieło, język, tradycja, Warszawa 1974, s. 152.

13 Tamże, s. 122.

14 R. Nycz, Poetyka doświadczenia. Teoria - nowoczesność - literatura, Warszawa 2012, s. 31.

15 Tamże.
} 
dzialny, jako taki bowiem odczytywać trzeba metapoetycki namysł nad reprezentacją śmierci w poezji towarzyszący lekturze nekrologu Heleny Wielogórskiej.

Wspomnieć trzeba, że motyw nekrologu pełni swoją metapoetycką funkcję również w wierszach mówiących wprost o polskiej poezji współczesnej. Są to dwa sąsiadujące ze sobą utwory, w których powtórzone zostaje określenie „współczesna poezja polska”. W pierwszym wierszu poeta pisze: „nekrologi będą zawsze / czymś więcej aniżeli współczesna poezja / polska na którą nikt się nie rzuca” [CCCXXXVI., OW, s. 376], w drugim „współczesna poezja polska to nekrologi" [CCCXXXVII., OW, s. 377]. Do cyklu zalicza się wiersz opowiadający o księgozbiorach, w którym poeta mówi „bądźmy szczerzy księgozbiory nie są / nam dziś potrzebne przeczytaj nekrolog" [CCCXXXV., OW, s. 375].

Tkaczyszyn-Dycki funkcjonalizuje nekrolog w różny sposób, czyniąc z niego metaforę własnego wiersza albo przeciwieństwo tekstu literackiego. We wszystkich omówionych utworach kreuje sytuację lektury-pisania, wskazującą na problematykę metapoetycką. Przywołanie nekrologu w tekście poetyckim tworzy sytuację "tekstu w tekście” i prowadzi ku rozważaniom metapoetyckim na temat przedstawienia śmierci. W swoich wierszach poeta charakteryzuje siebie jako jednostkę skoncentrowaną na przeszłości, więc jednocześnie na śmierci. Nie oznacza to, że rolą postaci pojawiających się $\mathrm{w}$ tej poezji jest stworzyć tło dla egocentrycznej ekspresji mówiącego. W świetle uwagi rzuconej mimochodem $\mathrm{w}$ innym zbiorze, "poeta zrobi wiersz z każdego / ździebka choćby z nekrologu" [XLV., IZ, s. 49], zdanie „współczesna poezja polska to nekrologi” traktować trzeba jako autokomentarz. Upodobnienie wierszy do nekrologów Tkaczyszyn-Dycki komentuje $\mathrm{w}$ sposób ironiczny $\mathrm{w}$ wierszu przedstawiającym dziewczynę czytającą nekrologi, którą przyrównać można do czytelniczki jego poezji. Obsesyjne zainteresowanie tematyką śmierci może w czytelniku wzbudzać niezrozumienie, podobne do niezrozumienia przebiegającej wzrokiem gazetę dziewczyny.

Metapoetyckie refleksje Tkaczyszyna-Dyckiego mają również swoje historycznoliterackie umocowanie $\mathrm{w}$ tradycji. Autor, nadając wierszom elegijnym funkcję metapoetycką, wpisuje się swoją twórczością $\mathrm{w}$ tradycję zapoczątkowaną przez Jana Kochanowskiego, który w Trenach poszukuje sposobu na transformację poetyk normatywnych swojej epoki. Teresa Banaś-Korniak zwraca uwagę na traktowanie przez Kochanowskiego zasady decorum, kiedy dopasowuje formę poematu do przedmiotu przedstawienia wedle kryteriów ustalonych przez siebie samego. Pozwoliło mu to zastosować formę trenu, poematu podniosłego, opisującego wybitną postać, 
do opisu małej dziewczynki ${ }^{16}$. W przypadku Tkaczyszyna-Dyckiego rozważania nad decorum przyjmują odpowiednią dla poezji współczesnej formę metapoetyckiej refleksji nad rolą aktu pisania-czytania w perspektywie doświadczenia śmierci. Obecność nekrologu w roli „tekstu w tekście” nie odbiera tej poezji funkcji poznawczej, podobnie jak stosowana przez autora ironia. Tkaczyszyn-Dycki stanowi raczej przykład twórcy korzystającego z tradycji elegijnej, który za sprawą oryginalnej nekrologii postrzega śmierć jako afektywno-językowe doświadczenie.

\section{Bibliografia}

Banaś-Korniak Teresa (2013), Zgodnie z zasadą decorum. Przyczynek do wyjaśnienia wątków metapoetyckich w "Trenach” Jana Kochanowskiego, „Napis. Pismo poświęcone literaturze okolicznościowej i użytkowej", nr 19, s. 13-27.

Głowiński Michał (1998), Zaświat przedstawiony. Szkice o poezji Bolesława Leśmiana, Kraków: Universitas.

Głowiński Michał (2000), Intertekstualność, groteska, parabola. Szkice ogólne i interpretacje, Kraków: Universitas.

Jaworski Marcin, Śniedziewski Piotr (2011), Od redakcji, „Poznańskie Studia Polonistyczne", nr 18, s. 7-10.

Kolbuszewski Jacek (1997), Z głębokim żalem... O wspótczesnej nekrologii, Wrocław: Wydawnictwo Uniwersytetu Wrocławskiego.

Legeżyńska Anna (1999), Gest pożegnania. Szkice o poetyckiej świadomości elegijno-ironicznej, Poznań: Rebis.

Nycz Ryszard (2012), Poetyka doświadczenia. Teoria - nowoczesność - literatura, Warszawa: Wydawnictwo IBL PAN.

Sławiński Janusz (1974), Semantyka wypowiedzi narracyjnej, w: J. Sławiński, Dzieło, język, tradycja, Warszawa: Państwowe Wydawnictwo Naukowe, s. 120-156.

Sosnowski Andrzej (2001), Liryzm Dyckiego, w: „jesień już Panie a ja nie mam domu”. Eugeniusz Tkaczyszyn-Dycki i krytycy, red. G. Jankowicz, Kraków: Stowarzyszenie na Rzecz Kultury Krakowa „Krakowska Alternatywa”, s. 44-50.

Świeściak Alina (2010), Melancholia w poezji polskiej po 1989 roku, Kraków: Universitas. Tkaczyszyn-Dycki Eugeniusz (2010), Oddam wiersze w dobre ręce (1988-2010), Wrocław: Biuro Literackie.

16 Zob. T. Banaś-Korniak, Zgodnie z zasada decorum. Przyczynek do wyjaśnienia wątków metapoetyckich w „Trenach" Jana Kochanowskiego, „Napis. Pismo poświęcone literaturze okolicznościowej i użytkowej" 2013, nr 19. 


\title{
Obituary as a Component of the Elegiac Poetic World and as a Meta-poetic Text in the Selected Pieces by Eugeniusz Tkaczyszyn-Dycki
}

\begin{abstract}
The article interprets the selected poems by Eugeniusz Tkaczyszyn-Dycki which use the trope of obituary. The author points out its functions. First, the obituary introduces an elegiac tone that characterizes the poet as a melancholic subject, focused on the theme of a funeral. Second, this form has a meta-poetic function which allows an affective and linguistic reflection on the experience of death.
\end{abstract}

Keywords: necrology, meta-poetics, autothematism, elegy, poetry 